\title{
Serum Transforming Growth Factor-Beta 1 Level in Egyptian Systemic Lupus Erythematosus Patients
}

\author{
Manal EL MENYAWI@, Mary FAWZY@, Mohamed HABIB @ , Olfat SHAKER (1) \\ Department of Internal Medicine, Cairo University, Cairo, Egypt
}

\begin{abstract}
Objectives: This study aims to assess the role of transforming growth factor-beta 1 (TGF- $\beta 1$ ) in systemic lupus erythematosus (SLE).

Patients and methods: The study included 40 female SLE patients (mean age $25.5 \pm 6.2$ years; range 15 to 39 years) diagnosed according to the American College of Rheumatology criteria and 30 female healthy controls (mean age $26.2 \pm 5.9$ years; range 16 to 39 years). Disease activity was assessed using SLE Disease Activity Index. Patients were diagnosed with lupus nephritis if they met the criteria for renal disorder. SLE patients and controls were compared in terms of TGF- $\beta 1$, low and high density lipoprotein, and triglyceride levels.

Results: Mean serum TGF- $\beta 1$ level of patients with SLE was $1385.7 \pm 483.1 \mathrm{pg} / \mathrm{mL}$, with a significant difference compared to control group $(2079.6 \pm 125.4 \mathrm{pg} / \mathrm{mL} ; \mathrm{p}<0.001)$. TGF- $\beta 1$ was statistically significantly correlated with SLE disease duration. However, there was no statistically significant correlation between TGF- $\beta 1$ and erythrocyte sedimentation rate, C-reactive protein, 24-hour urinary protein, complement 3, serum cholesterol, low density lipoprotein, or serum triglyceride. TGF- $\beta 1$ was statistically significantly correlated with discoid rash. There was a statistically significant correlation between SLE Disease Activity Index and serum cholesterol, and triglyceride.

Conclusion: Systemic lupus erythematosus patients had lower levels of TGF- $\beta 1$, without any significant correlation with SLE Disease Activity Index or lipid profile. TGF- $\beta 1$ had a significant correlation with discoid lupus.

Keywords: Discoid lupus; systemic lupus erythematosus; transforming growth factor-beta 1.
\end{abstract}

Systemic lupus erythematosus (SLE) is a generalized autoimmune disorder characterized by $\mathrm{T}$ and $\mathrm{B}$ cell hyperactivity with autoantibodies against numerous cell components and deposition of immune complexes. The disease has a multifactorial pathogenesis with genetic, hormonal and environmental components. ${ }^{1}$ Regulatory $\mathrm{T}$ cells play an important role in the maintenance of immune tolerance to self and in the pathogenesis of autoimmune disease. Transforming growth factor-beta 1 (TGF- $\beta 1$ ) is a regulatory cytokine with pleiotropic properties in immune responses. ${ }^{2}$ TGF- $\beta 1$ is the most potent naturally occurring immunosuppressant.
TGF- $\beta 1$, which belongs to the TGF- $\beta$ family of proteins, is secreted by a variety of cell types with unique and potent immunomodulatory properties in the maintenance of normal immunological homeostasis. ${ }^{3}$ TGF- $\beta 1$ displays multiple functions which, depending on the responding cell type and the state of differentiation, are sometimes opposing. ${ }^{4}$ Preliminary human studies suggest that TGF- $\beta 1$ expression in SLE may be dysregulated. Production of TGF- $\beta 1$ by lymphocytes isolated from SLE patients is reduced compared with that in control individuals. ${ }^{5}$ And this may contribute to the characteristic $\mathrm{T}$ cell dysregulation and aberrant B cell stimulation in SLE patients. ${ }^{6}$

Received: February 26, 2017 Accepted: April 03, 2017 Published online: July 31, 2018

Correspondence: Mary Fawzy, MD. Department of Internal Medicine, Cairo University, 12311 Cairo, Egypt. Tel: 00201006196952 e-mail: drmarywadie@yahoo.com 
Table 1. Clinical presentation of systemic lupus erythematosus

\begin{tabular}{lccllll|}
\hline & \multicolumn{2}{c}{ Patients $(\mathrm{n}=40)$} & & \multicolumn{2}{c}{ Controls $(\mathrm{n}=30)$} \\
\cline { 2 - 3 } \cline { 6 - 7 } & $\mathrm{n}$ & $\%$ & & $\mathrm{n}$ & $\%$ \\
\hline Sex & 40 & 100.0 & & 30 & 100.0 \\
$\quad$ Female & 20 & 50.0 & & & \\
Arthritis & & & & & \\
Mucocutaneous & 29 & 72.5 & & & \\
Malar rash & 6 & 15.0 & & & \\
Discoid rash & 36 & 90.0 & & & \\
Photosensitivity & 3 & 7.5 & & & \\
Oral ulcer & 4 & 10.0 & & & \\
Cutaneous vasculitis & & & &
\end{tabular}

Therefore, in this study, we aimed to assess the role of TGF- $\beta 1$ in SLE.

\section{PATIENTS AND METHODS}

The study was conducted between May 2015 and December 2016 and included 40 female Egyptian SLE patients (mean age $25.5 \pm 6.2$ years; range 15 to 39 years) diagnosed according to the American College of Rheumatology criteria ${ }^{7}$ from Internal Medicine and Rheumatology \& Rehabilitation Outpatient Clinics. Thirty female age-matched healthy controls (mean age $26.2 \pm 5.9$ years; range 16 to 39 years) from a similar ethnic background were also included. Clinical activity was assessed at the time of venipuncture using the Systemic Lupus Erythematosus Disease Activity Index (SLEDAI). The study protocol was approved by the Faculty of Medicine, Cairo University Ethics Committee. The study was conducted in accordance with the principles of the Declaration of Helsinki.

All patients were subjected to full clinical history and thorough examination, laboratory investigations in the form of complete blood count, erythrocyte sedimentation rate, $\mathrm{C}$-reactive protein, complement 3 (C3), $\mathrm{C} 4$, serum creatinine, anti-double stranded deoxyribonucleic acid antibody, serum cholesterol, serum triglyceride, low density lipoprotein (LDL) cholesterol, high density lipoprotein cholesterol, urine analysis, 24-hour urinary protein, serum TGF- $\beta 1$ (quantitation of tumor necrosis factor-beta 1 [TGF- $\beta 1$ ] in serum was performed by using TGF- $\beta$ enzyme-linked immunosorbent assay kits provided by AviBion, Helsinki, Finland). Immediately after blood sampling, serum was obtained by centrifugation at $800 \mathrm{~g}$ at $4^{\circ} \mathrm{C}$ for 15 minutes and stored at $70^{\circ} \mathrm{C}$. The minimum detectable dose of TGF- $\beta 1$ is $1.7 \mathrm{pg} / \mathrm{mL}$. This was determined by adding two standard deviations (SDs) to the mean optical density obtained when the zero standard was assayed 20 times.

Table 2. Clinical and laboratory data of systemic lupus erythematosus patients and controls

\begin{tabular}{|c|c|c|c|c|}
\hline & Patients & & Controls & \\
\hline & Mean \pm SD & Min-Max & Mean \pm SD & Min-Max \\
\hline Age (year) & $25.5 \pm 6.2$ & $15-39$ & $26.2 \pm 5.9$ & $16-39$ \\
\hline Systemic Lupus Erythematosus Disease Activity Index & $14.1 \pm 9.3$ & $2-28$ & & \\
\hline Disease duration (month) & $3.0 \pm 3.2$ & $0.3-12$ & & \\
\hline Hemoglobin (\%) & $10.3 \pm 1.6$ & $7.2-14.3$ & & \\
\hline Total leucocytic count & $7.5 \pm 3.5$ & $2.9-18$ & & \\
\hline Lymphocyte & $25.6 \pm 16.4$ & 4-85 & & \\
\hline Neutrophil & $68.5 \pm 17.4$ & 9.4-93 & & \\
\hline Platelet & $243.7 \pm 93.3$ & 45-442 & & \\
\hline Creatinine $(\mathrm{mg} / \mathrm{dL})$ & $0.8 \pm 0.5$ & $0.4-3$ & & \\
\hline Urea $(\mathrm{mg} / \mathrm{dL})$ & $33.1 \pm 22.9$ & 8-114 & & \\
\hline Erythrocyte sedimentation rate & $50.9 \pm 34.6$ & $6-140$ & & \\
\hline C-reactive protein $(\mathrm{mg} / \mathrm{dL})$ & $6.5 \pm 15.8$ & $1-96$ & & \\
\hline Complement 3 & $95.9 \pm 48.5$ & $11-193$ & & \\
\hline Complement 4 & $15.9 \pm 9.5$ & $2-48$ & & \\
\hline 24-h urinary protein & $1.2 \pm 1.4$ & $0.03-5$ & & \\
\hline Total cholesterol (mg/dL) & $214.0 \pm 71.8$ & $102-352$ & $169.7 \pm 18.3$ & $133-200$ \\
\hline Low density lipoprotein (mg/dL) & $113.5 \pm 43.1$ & 46-182 & $92.5 \pm 17.0$ & 59-116 \\
\hline High density lipoprotein (mg/dL) & $52.7 \pm 14.2$ & $26-85$ & $54.9 \pm 14.1$ & $35-97$ \\
\hline Triglyceride $(\mathrm{mg} / \mathrm{dL})$ & $135.8 \pm 85.0$ & $32-396$ & $77.3 \pm 33.5$ & $32-138$ \\
\hline Transforming growth factor beta level & $1385.7 \pm 483.1$ & $450-2110$ & $2079.6 \pm 125.4$ & $1825-2447$ \\
\hline
\end{tabular}


Table 3. Correlation between clinical data in patients with arthritis, mucocutaneous and transforming growth factor beta 1

\begin{tabular}{|c|c|c|}
\hline & TGF- $\beta 1$ level & \\
\hline & Mean \pm SD & $p$ \\
\hline Arthriti & & \\
\hline Yes & $1261.3 \pm 433.2$ & 0.1 \\
\hline No & $1510.1 \pm 508.8$ & NS \\
\hline Malar $r$ & & \\
\hline Yes & $1410.5 \pm 475.3$ & 0.6 \\
\hline No & $1320.2 \pm 520.9$ & NS \\
\hline Discoid & & \\
\hline Yes & $1051.5 \pm 31.4$ & $<0.001$ \\
\hline No & $1444.7 \pm 501.8$ & HS \\
\hline Photose & & \\
\hline Yes & $1361.4 \pm 481.3$ & 0.3 \\
\hline No & $1603.8 \pm 510.9$ & NS \\
\hline Oral Ul & & \\
\hline Yes & $1270.7 \pm 471.2$ & 0.7 \\
\hline No & $1395.0 \pm 489.2$ & NS \\
\hline Cutane & & \\
\hline Yes & $1536.0 \pm 486.6$ & 0.5 \\
\hline No & $1369.0 \pm 486.8$ & NS \\
\hline Active 1 & & \\
\hline Yes & $1374.6 \pm 458.4$ & 0.9 \\
\hline No & $1398.0 \pm 521.5$ & NS \\
\hline
\end{tabular}

Patients were diagnosed with lupus nephritis if they met the following criteria for renal disorder: (i) persistent proteinuria of $0.5 \mathrm{gm} / 24$ hour (or more than +3 dipstick reactions for albumin), or (ii) cellular casts including red blood cell, granular, renal tubular epithelial cell or mixed cellular casts. ${ }^{8}$ Patients with malignancy or other autoimmune diseases were excluded.

\section{Statistical analysis}

Data were coded and entered using the IBM SPSS Statistics version 21.0 program (IBM Corp., Armonk, NY, USA). Data were summarized using descriptive statistics: mean, standard deviation, minimal and maximum values for quantitative variables and number and percentage for qualitative values. Statistical differences between groups were tested using independent sample t-test for quantitative variables. Pearson and Spearman correlation coefficients were calculated to test the association between quantitative and ordinal variables, respectively. $P$ values of $>0.05$ were considered as insignificant, $<0.05$ as significant, and $<0.01$ as highly significant.

\section{RESULTS}

Of the 40 SLE patients, 20 (50\%) presented with arthritis and 29 (72\%) with malar rash. Six patients (15\%) had discoid rash and 36 (90\%) had photosensitivity. Three patients (7.5\%) had

Table 4. Comparison between dyslipidemic and non-dyslipidemic systemic lupus erythematosus patients

\begin{tabular}{|c|c|c|c|}
\hline & $\begin{array}{l}\text { Group } 1(\mathrm{n}=25) \\
\text { Dyslipidemic SLE }\end{array}$ & $\begin{array}{c}\text { Group } 2(\mathrm{n}=15) \\
\text { Non-dyslipidemic SLE }\end{array}$ & \\
\hline & Mean \pm SD & Mean \pm SD & $p$ \\
\hline Age (year) & $23.8 \pm 5.5$ & $28.2 \pm 6.6$ & $0.03^{*}$ \\
\hline Disease duration & $2.5 \pm 3.1$ & $3.8 \pm 3.2$ & $0.2 \dagger$ \\
\hline SLEDAI & $16.5 \pm 8.9$ & $10.0 \pm 8.8$ & $0.03^{*}$ \\
\hline TGF- $\beta 1$ (pg/mL) & $1380.2 \pm 442.5$ & $1394.8 \pm 560.7$ & $0.9 \dagger$ \\
\hline
\end{tabular}

Table 5. Laboratory correlation between patients and controls

\begin{tabular}{|c|c|c|c|}
\hline & Patients $(n=40)$ & Controls $(n=30)$ & \\
\hline & Mean \pm SD & Mean \pm SD & $p$ \\
\hline Total cholesterol & $214.0 \pm 71.8$ & $169.7 \pm 18.3$ & $0.001^{*}$ \\
\hline Low density lipoprotein & $113.5 \pm 43.1$ & $92.5 \pm 17.0$ & $0.01 \dagger$ \\
\hline High density lipoprotein & $52.7 \pm 14.2$ & $54.9 \pm 14.1$ & $0.5 \neq$ \\
\hline Triglycerides & $135.8 \pm 85.0$ & $77.3 \pm 33.5$ & $<0.001^{*}$ \\
\hline Transforming growth factor beta 1 level & $1385.7 \pm 483.1$ & $2079.6 \pm 125.4$ & $<0.001^{*}$ \\
\hline
\end{tabular}


Table 6. Correlation between disease duration, Systemic Lupus Erythematosus Disease Activity Index, laboratory findings and serum transforming growth factor beta 1 level

\begin{tabular}{|c|c|}
\hline & TGF- $\beta 1$ level \\
\hline \multicolumn{2}{|l|}{ Disease duration } \\
\hline Spearman correlation coefficient & 0.324 \\
\hline$p$ & 0.04 \\
\hline \multicolumn{2}{|l|}{ Erythrocyte sedimentation rate } \\
\hline $\mathrm{r}$ & 0.056 \\
\hline$p$ & 0.7 \\
\hline \multicolumn{2}{|l|}{ C-reactive protein } \\
\hline r & -0.045 \\
\hline$p$ & 0.8 \\
\hline \multicolumn{2}{|l|}{ 24-h urinary protein } \\
\hline $\mathrm{r}$ & -0.11 \\
\hline$p$ & 0.5 \\
\hline \multicolumn{2}{|l|}{ Complement 3} \\
\hline r & 0.146 \\
\hline$p$ & 0.4 \\
\hline \multicolumn{2}{|l|}{ Complement 4} \\
\hline r & 0.051 \\
\hline$p$ & 0.8 \\
\hline \multicolumn{2}{|l|}{ Total cholesterol } \\
\hline r & 0.007 \\
\hline$p$ & 0.9 \\
\hline \multicolumn{2}{|l|}{ Low density lipoprotein } \\
\hline $\mathrm{r}$ & -0.03 \\
\hline$p$ & 0.9 \\
\hline \multicolumn{2}{|l|}{ High density lipoprotein } \\
\hline $\mathrm{r}$ & 0.096 \\
\hline$p$ & 0.6 \\
\hline \multicolumn{2}{|l|}{ Triglyceride } \\
\hline $\mathrm{r}$ & -0.165 \\
\hline$p$ & 0.3 \\
\hline \multicolumn{2}{|l|}{ SLEDAI } \\
\hline r & -0.056 \\
\hline$p$ & 0.7 \\
\hline \multicolumn{2}{|l|}{ Platelet } \\
\hline r & 0.239 \\
\hline$p$ & 0.1 \\
\hline \multicolumn{2}{|l|}{ Hemoglobin } \\
\hline r & 0.074 \\
\hline$p$ & 0.7 \\
\hline \multicolumn{2}{|l|}{ Total leucocytic count } \\
\hline $\mathrm{r}$ & 0.06 \\
\hline$p$ & 0.7 \\
\hline \multicolumn{2}{|l|}{ Lymphocyte } \\
\hline $\mathrm{r}$ & -0.075 \\
\hline$p$ & 0.6 \\
\hline \multicolumn{2}{|l|}{ Neutrophil } \\
\hline r & 0.061 \\
\hline$p$ & 0.7 \\
\hline
\end{tabular}

oral ulcers while four (10\%) had cutaneous vasculitis (Table 1). Disease duration ranged from 3 to 12 months with a mean of $3 \pm 3.2$ (Table 2). SLEAI ranged from 22 to 28 with a mean of

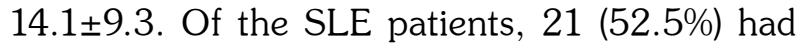
active lupus nephritis (Table 3) while 25 (62.5\%) were dyslipidemic (Table 4).

\begin{tabular}{|lc|}
\hline \multicolumn{2}{|l|}{ Table 7. Correlation of transforming growth factor beta } \\
and lipid profile in controls \\
\hline \multicolumn{2}{|c}{ TGF- $\beta$ l level } \\
\hline Total cholesterol \\
r & \\
$p$ & 0.045 \\
Low density lipoprotein & 0.812 \\
$r$ & 0.055 \\
$p$ & 0.771 \\
High density lipoprotein & 0.004 \\
$r$ & 0.984 \\
$p$ & -0.107 \\
Triglyceride & 0.573 \\
$r$ & \\
$p$ & \\
\hline TGF- $\beta$ 1: Transforming growth factor beta 1; r: Pearson correlation coefficient. \\
\hline
\end{tabular}

All SLE patients were on hydroxychloroquine at a dose of $5 \mathrm{mg} / \mathrm{kg}$. Of the patients, $20 \%$ were on low dose steroid, $15 \%$ were on moderate dose of steroids, $48 \%$ were on maintenance therapy of azathioprine $2.5 \mathrm{mg} / \mathrm{kg}, 30 \%$ were on cyclophosphamide induction therapy (500 mg every two weeks), and $22 \%$ were on mycophenolate mofetil $2 \mathrm{gm} /$ day.

Mean serum TGF- $\beta 1$ level of SLE patients was $1385.7 \pm 483.1 \mathrm{pg} / \mathrm{mL}$ with a significant difference compared with the control group $(2079.6 \pm 125.4 \mathrm{pg} / \mathrm{mL} ; \mathrm{p}<0.001)$. There was a statistically significant difference in total serum cholesterol, LDL, and serum triglyceride levels between SLE patients and controls, with higher levels in the first group ( $\mathrm{p}$ values of $0.001,0.01$, and $<0.001$, respectively) (Table 5).

Transforming growth factor-beta 1 was statistically significantly correlated with SLE disease duration with a $\mathrm{p}$ value of 0.04 . However, there was no statistically significant correlation between TGF- $\beta 1$ and erythrocyte sedimentation rate, $\mathrm{C}$-reactive protein, 24-hour urinary protein, $\mathrm{C} 3$, serum cholesterol, LDL, and serum triglyceride levels (Table 6,7 ). TGF- $\beta 1$ was statistically significantly correlated with discoid rash with a $p$ value of $<0.01$. However, there was no statistically significant correlation between TGF- $\beta 1$ and arthritis, photosensitivity, oral ulcer, or malar rash ( $p>0.05)$ (Table 3).

Systemic Lupus Erythematosus Disease Activity Index was statistically significantly correlated with erythrocyte sedimentation rate, serum cholesterol, triglyceride, and 
Table 8. Correlation between erythrocyte sedimentation rate, C-reactive protein, Systemic Lupus Erythematosus Disease Activity Index, and lipid profile

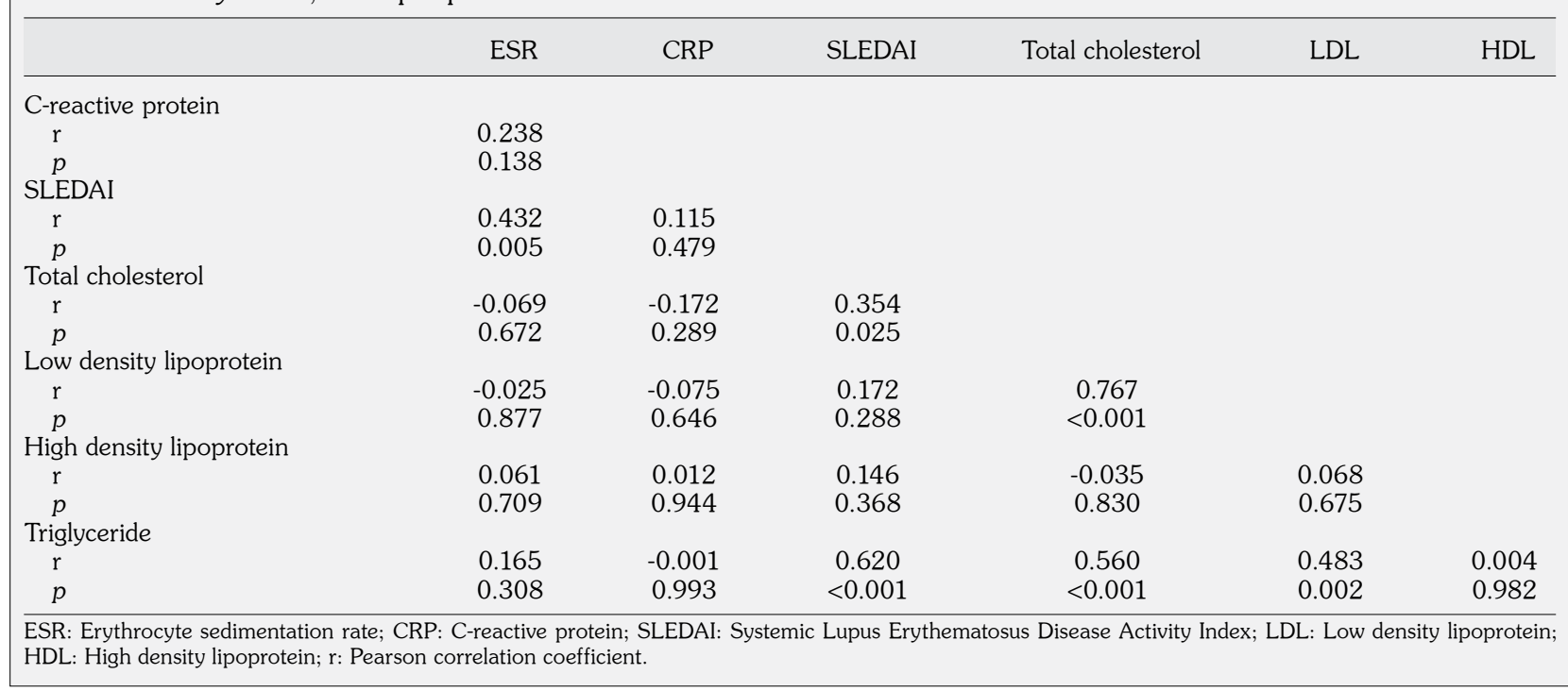

Table 9. Correlation between anti-deoxyribonucleic acid and laboratory findings, Systemic Lupus Erythematosus Disease Activity Index, and disease duration

\begin{tabular}{|c|c|}
\hline & Anti-DNA \\
\hline \multicolumn{2}{|c|}{ SLEDAI } \\
\hline Rho & 0.467 \\
\hline$p$ & 0.002 \\
\hline \multicolumn{2}{|c|}{ Disease duration } \\
\hline Rho & -0.462 \\
\hline$p$ & 0.003 \\
\hline \multicolumn{2}{|c|}{ Erythrocyte sedimentation rate } \\
\hline Rho & 0.223 \\
\hline$p$ & 0.167 \\
\hline \multicolumn{2}{|c|}{ C-reactive protein } \\
\hline Rho & 0.071 \\
\hline$p$ & 0.665 \\
\hline \multicolumn{2}{|c|}{ Complement 3} \\
\hline Rho & -0.659 \\
\hline$p$ & $<0.001$ \\
\hline \multicolumn{2}{|c|}{ Complement 4} \\
\hline Rho & -0.389 \\
\hline$p$ & 0.013 \\
\hline \multicolumn{2}{|c|}{ 24-h urinary protein } \\
\hline Rho & 0.415 \\
\hline$p$ & 0.008 \\
\hline \multicolumn{2}{|c|}{ Total cholesterol } \\
\hline Rho & -0.038 \\
\hline$p$ & 0.815 \\
\hline \multicolumn{2}{|c|}{ Low density lipoprotein } \\
\hline Rho & -0.03 \\
\hline$p$ & 0.855 \\
\hline \multicolumn{2}{|c|}{ High density lipoprotein } \\
\hline Rho & 0.433 \\
\hline \multirow{2}{*}{\multicolumn{2}{|c|}{ Triglyceride }} \\
\hline & \\
\hline Rho & 0.182 \\
\hline$p$ & 0.261 \\
\hline \multicolumn{2}{|c|}{ Transforming growth factor beta level } \\
\hline Rho & -0.18 \\
\hline$p$ & 0.267 \\
\hline
\end{tabular}

deoxyribonucleic acid levels ( $p$ values of $0.005,0.025,0.001$, and 0.002 , respectively) (Table 8). Deoxyribonucleic acid was statistically significantly correlated with disease duration, $\mathrm{C} 3, \mathrm{C} 4$, and 24-hour urinary protein ( $\mathrm{p}$ values of $0.003,0.001,0.013$, and 0.008 , respectively) (Table 9).

Transforming growth factor-beta 1 was not statistically significantly correlated with serum cholesterol, triglyceride, or LDL levels in the control group ( $p>0.05)$ (Table 10). There was no statistically significant difference in TGF- $\beta 1$ level between patients with high or low disease activity, between those with proteinuria of $>3 \mathrm{~g}$ or $<3 \mathrm{~g}$, and between those with serum creatinine of $>1.2 \mathrm{~g} / \mathrm{dL}$ or $<1.2 \mathrm{~g} / \mathrm{dL}$ (Table 11, 12, 13).

\section{DISCUSSION}

Systemic lupus erythematosus is a complex autoimmune disorder which involves various facets of the immune system. In addition to autoantibody production and immune complex deposition, emerging evidences suggest that cytokines may act as key players in the immunopathogenesis of SLE. ${ }^{9}$ Regulatory T cells play an important role in the maintenance of immune tolerance to self and in the pathogenesis of autoimmune disease. TGF- $\beta 1$ is a regulatory cytokine with pleiotropic properties in immune responses. ${ }^{2}$ 
Table 10. Correlation of lipid profile and transforming growth factor beta 1 in controls

\begin{tabular}{|c|c|c|c|c|}
\hline & TGF- $\beta 1$ level & Total cholesterol & HDL & LDL \\
\hline \multicolumn{5}{|c|}{ Total cholesterol } \\
\hline$r$ & 0.045 & & & \\
\hline$p$ & 0.812 & & & \\
\hline \multicolumn{5}{|c|}{ High density lipoprotein } \\
\hline $\mathrm{r}$ & 0.055 & 0.293 & & \\
\hline$p$ & 0.771 & 0.117 & & \\
\hline \multicolumn{5}{|c|}{ Low density lipoprotein } \\
\hline r & 0.004 & 0.527 & 0.156 & \\
\hline$p$ & 0.984 & 0.003 & 0.411 & \\
\hline \multicolumn{5}{|c|}{ Triglyceride } \\
\hline $\mathrm{r}$ & -0.107 & -0.141 & -0.273 & 0.111 \\
\hline$p$ & 0.573 & 0.459 & 0.144 & 0.557 \\
\hline
\end{tabular}

Table 11. Comparison between active lupus nephritis and non-active lupus nephritis

\begin{tabular}{lcccc}
\hline & $\begin{array}{c}\text { Group } 1(\mathrm{n}=21) \\
\text { Active LN }\end{array}$ & & $\begin{array}{c}\text { Group 2 }(\mathrm{n}=19) \\
\text { Non-active LN }\end{array}$ & \\
\cline { 2 - 2 } \cline { 5 - 5 } & Mean \pm SD & & Mean \pm SD & \\
\hline Disease duration & $2.1 \pm 2.2$ & & $3.9 \pm 3.8$ & $0.08 \dagger$ \\
SLEDAI & $21.8 \pm 3.7$ & & $5.5 \pm 4.9$ & $<0.001 \neq$ \\
TGF- $\beta 1$ & $1374.6 \pm 458.4$ & & $1398.0 \pm 521.5$ & $0.9 \dagger$ \\
\hline
\end{tabular}

LN: Lupus nephritis; SD: Standard deviation; * Significant; † Non-significant; キ Highly significant; TGF- $\beta 1$ : Transforming growth factor-beta 1 .

Table 12. Comparison between serum transforming growth factor beta 1 levels and creatinine, complement 3 , and proteinuria in systemic lupus erythematosus patients

\begin{tabular}{|c|c|c|c|c|c|}
\hline & \multicolumn{3}{|c|}{ TGF- $\beta 1$ level } & \multicolumn{2}{|c|}{ T-test } \\
\hline & $\mathrm{n}$ & Range & Mean \pm SD & $\mathrm{t}$ & $p$ \\
\hline \multicolumn{6}{|l|}{ Creatinine } \\
\hline$<1.2$ & 36 & $450-2110$ & $1355.7 \pm 488.8$ & \multirow{2}{*}{0.308} & \multirow{2}{*}{0.760} \\
\hline$\geq 1.2$ & 4 & $919-2087$ & $1419.2 \pm 556.9$ & & \\
\hline \multicolumn{6}{|c|}{ 24-h urinary protein } \\
\hline $\begin{array}{l}<3 \\
>3\end{array}$ & 26 & $450-2110$ & $1430.4 \pm 532.2$ & \multirow[t]{2}{*}{1.190} & \multirow[t]{2}{*}{0.243} \\
\hline \multicolumn{4}{|l|}{ Complement 3} & & \\
\hline Consumed & 19 & $536-2076$ & $1277.8 \pm 458.3$ & \multirow{2}{*}{0.936} & \multirow{2}{*}{0.357} \\
\hline Not consumed & 21 & $450-2110$ & $1444.0 \pm 527.9$ & & \\
\hline
\end{tabular}

Table 13. Comparison between serum transforming growth factor beta 1 levels in systemic lupus erythematosus patients with mild to moderate versus higher disease activity

\begin{tabular}{|c|c|c|c|c|c|}
\hline \multirow[b]{2}{*}{ SLEDAI } & \multicolumn{3}{|c|}{ TGF- $\beta 1$ level } & \multicolumn{2}{|c|}{ T-test } \\
\hline & $\mathrm{n}$ & Range & Mean \pm SD & $\mathrm{t}$ & $p$ \\
\hline Mild to moderate & 17 & $450-2110$ & $1363.48 \pm 521.95$ & \multirow{2}{*}{0.064} & \multirow{2}{*}{0.950} \\
\hline Higher activity & 23 & $536-2087$ & $1375.55 \pm 498.54$ & & \\
\hline
\end{tabular}


In this study, we tried to assess the relationship between serum TGF- $\beta 1$ level and different clinical and laboratory findings in SLE patients, and whether there was any difference between SLE patients and controls in terms of serum TGF- $\beta 1$ level.

A number of circulating cytokine abnormalities have been reported in SLE and recent advances have revealed new insights in cytokine regulation of autoimmune inflammatory responses. In particular, the production of interleukin-10 and TGF- $\beta 1$, the two main regulatory $T$ cytokines that suppress the inflammatory response, has been found to be deeply deregulated in SLE patients, so they have been considered essential elements in the etiopathology of the disease. ${ }^{10}$ TGF- $\beta 1$ is a highly pleiotropic cytokine with an important role in maintaining immune homeostasis. ${ }^{11}$ TGF- $\beta 1$ is involved in many critical cellular processes, including cell growth, extracellular matrix formation, cell motility, hematopoiesis, apoptosis and immune function. ${ }^{12}$ TGF- $\beta 1$ has pronounced antiinflammatory and immunosuppressive functions, the latter being realized by controlling the activation, proliferation, differentiation and survival of all effectors immune cells. ${ }^{13}$

In our study, there was a statistical significant difference in serum TGF- $\beta 1$ levels between SLE patients and controls with lower values detected in SLE patients with a $\mathrm{p}$ value less than 0.001 . This was in agreement with the results of Becker-Merok et al., ${ }^{14}$ who revealed that patients with SLE had lower levels of TGF- $\beta 1 \quad(p=0.01)$ and interleukin-1 $\beta \quad(p=0.0004)$ compared to controls.

Discoid LE may occur either as a cutaneous eruption without systemic disease or as part of SLE. In biopsy specimens of discoid LE, CD $4^{+} \mathrm{T}$ cells are the predominant cells. ${ }^{15}$ Three distinct subsets of T-helper lymphocytes that vary in their cytokine expression patterns have been identified in mice and humans: ${ }^{16} \mathrm{~T}$ helper 1 (Th1), and Th2. In our study, there was a statistically significant difference in TGF- $\beta 1$ between SLE patients with $(1051.5 \pm 31.4)$ or without $(1444.7 \pm 501.8)$ discoid rash, with lower value in those with discoid rash with a $p$ value less than 0.001. This was in agreement with Antiga et al., ${ }^{17}$ who concluded that the down regulation of TGF- $\beta 1$ and interleukin-10 in discoid LE may lead to defective immune suppression and thus to the generation of the tissue injury that is found in lupus patients.

Furthermore, we demonstrated that TGF- $\beta 1$ was statistically significantly correlated with disease duration, which contradicted the findings of Jackson et al., ${ }^{18}$ who concluded that TGF- $\beta 1$ in SLE patients inversely correlated with disease duration (Pearson $\mathrm{r}=-0.377, \mathrm{p}=0.033$ ). This may be related to prolonged disease duration in their study (mean disease duration of $13 \pm 5.8$ years); however, our patients had shorter disease duration of $3 \pm 3.2$ months.

Transforming growth factor beta 1 is a multifunctional growth factor peptide reported to be involved in many physiologic and pathologic processes, such as vascular remodeling and atherogenesis. ${ }^{19}$

In our study, we found 21 patients with active nephritis, while we detected no statistically significant difference in serum TGF- $\beta 1$ between active and non-active lupus nephritis group. Moreover, there was no statistically significant difference in TGF- $\beta 1$ levels between patients with proteinuria more or less than $3 \mathrm{~g}$. This was in contrary to Jin et al., ${ }^{21}$ who showed significantly lower levels of total TGF- $\beta 1$ in patients with severe renal damage, i.e. lower TGF- $\beta 1$ in patients with 24-hour urine protein of over $3.5 \mathrm{~g}$ than in those with below $3.5 \mathrm{~g}(\mathrm{p}<0.05)$. This may be related to sample size as his sample included 150 SLE patients.

No significant correlation was found between serum TGF- $\beta 1$ and SLEDAI score in our SLE patients $(r=-0.056, p=0.7)$, which conformed with the study of Q. Xing et al., ${ }^{2}$ which was conducted on 42 SLE patients and 26 healthy controls and showed no significant correlation between serum TGF- $\beta 1$ levels and SLEDAI scores in SLE group $(\mathrm{r}=0.049, \mathrm{p}>0.05)$.

Furthermore, we divided our SLE patients into different subgroups according to their SLEDAI score. Accordingly, the number of patients with mild to moderate SLEDAI scores was 17 (42.5\%), while the number of patients with high SLEDAI scores was 23 (57.5\%). A comparison of the serum levels of TGF- $\beta 1$ in SLE patients as regards to their SLEDAI score revealed no statistically significant difference 
between serum TGF- $\beta 1$ levels in patients with mild to moderate SLEDAI scores and patients with high SLEDAI scores $(p=0.950)$. This finding disagreed with findings of Jin et al., ${ }^{20}$ who found that total TGF- $\beta 1$ levels were lower in patients with high disease activity. This may be due to their larger sample size.

Renal TGF- $\beta 1$ is a key mediator of glomerular and tubulo-interstitial pathobiology in renal diseases. Over expression of TGF- $\beta 1$ isoforms and their receptors in the kidney of experimental animals are closely linked to renal fibrosis, a characteristic feature of progressive proteinuric nephropathies. ${ }^{21}$

We found no significant correlation between TGF- $\beta 1$ and 24-hour urinary protein $(r=-0.11, p=0.5)$. This was in agreement with $Q$. Xing et al; ${ }^{10}$ who found no significant correlation between serum TGF- $\beta 1$ levels and 24-hour urine protein $(\mathrm{r}=-0.239, \mathrm{p}>0.05)$.

The limitation of this study was our small sample size. Therefore, further studies with larger sample sizes are required to investigate the role of TGF- $\beta 1$ in SLE.

In conclusion, we detected lower levels of serum TGF- $\beta 1$ in SLE patients, with no statistically significant correlation between TGF- $\beta 1$ and SLEDAI, or lipid profile. Moreover, there was no statistically significant difference in TGF- $\beta 1$ between dyslipidemic and non-dyslipidemic lupus patients, and in active and non-active lupus nephritis. On the other hand, there was a statistically significant correlation between TGF- $\beta 1$ and discoid lupus with no correlation to any other clinical manifestation of lupus, which may raise the possibility that TGF- $\beta 1$ may be a diagnostic marker for discoid lupus. Finally, there was a statistically significant correlation between serum cholesterol and triglyceride levels with SLEDAI.

\section{Declaration of conflicting interests}

The authors declared no conflicts of interest with respect to the authorship and/or publication of this article.

\section{Funding}

The authors received no financial support for the research and/or authorship of this article.

\section{REFERENCES}

1. Mok CC, Lau CS. Pathogenesis of systemic lupus erythematosus. J Clin Pathol 2003;56:481-90.

2. Xing Q, Su H, Cui J, Wang B. Role of Treg cells and TGF- $\beta 1$ in patients with systemic lupus erythematosus: a possible relation with lupus nephritis. Immunol Invest 2012;41:15-27.

3. Letterio $\mathrm{JJ}$, Roberts $\mathrm{AB}$. Regulation of immune responses by TGF-beta. Annu Rev Immunol 1998;16:137-61.

4. Wahl SM. Transforming growth factor beta: the good, the bad, and the ugly. J Exp Med 1994;180:1587-90.

5. Ohtsuka K, Gray JD, Stimmler MM, Toro B, Horwitz DA. Decreased production of TGF-beta by lymphocytes from patients with systemic lupus erythematosus. J Immunol 1998;160:2539-45.

6. Schotte H, Willeke P, Rust S, Assmann G, Domschke $\mathrm{W}$, Gaubitz $\mathrm{M}$, et al. The transforming growth factor-beta1 gene polymorphism (G915C) is not associated with systemic lupus erythematosus. Lupus 2003;12:86-92.

7. Hochberg MC. Updating the American College of Rheumatology revised criteria for the classification of systemic lupus erythematosus. Arthritis Rheum 1997;40:1725.

8. Balow JE. Clinical presentation and monitoring of lupus nephritis. Lupus 2005;14:25-30.

9. Yap DY, Lai KN. Cytokines and their roles in the pathogenesis of systemic lupus erythematosus: from basics to recent advances. J Biomed Biotechnol 2010;2010:365083.

10. Diveu C, McGeachy MJ, Cua DJ. Cytokines that regulate autoimmunity. Curr Opin Immunol 2008;20:663-8.

11. Li MO, Wan YY, Sanjabi S, Robertson AK, Flavell RA. Transforming growth factor-beta regulation of immune responses. Annu Rev Immunol 2006;24:99-146.

12. Moustakas A, Pardali K, Gaal A, Heldin $\mathrm{CH}$. Mechanisms of TGF-beta signaling in regulation of cell growth and differentiation. Immunol Lett 2002;82:85-91.

13. Rubtsov YP, Rudensky AY. TGFbeta signalling in control of T-cell-mediated self-reactivity. Nat Rev Immunol 2007;7:443-53.

14. Becker-Merok A, Eilertsen GØ, Nossent JC. Levels of transforming growth factor-beta are low in systemic lupus erythematosus patients with active disease. J Rheumatol 2010;37:2039-45.

15. Rijlaarsdam JU, Nieboer C, de Vries E, Willemze R. Characterization of the dermal infiltrates in Jessner's lymphocytic infiltrate of the skin, polymorphous light eruption and cutaneous lupus erythematosus: differential diagnostic and pathogenetic aspects. J Cutan Pathol 1990;17:2-8. 
16. Carter LL, Dutton RW. Type 1 and type 2: a fundamental dichotomy for all T-cell subsets. Curr Opin Immunol 1996;8:336-42.

17. Antiga E, Del Bianco E, Difonzo E, Fabbri P, Caproni M. Serum levels of the regulatory cytokines transforming growth factor- $\beta$ and interleukin-10 are reduced in patients with discoid lupus erythematosus. Lupus 2011;20:556-60.

18. Jackson M, Ahmad Y, Bruce IN, Coupes B, Brenchley $\mathrm{PE}$. Activation of transforming growth factor-beta1 and early atherosclerosis in systemic lupus erythematosus.
Arthritis Res Ther 2006;8:R81.

19. Blobe GC, Schiemann WP, Lodish HF. Role of transforming growth factor beta in human disease. N Engl J Med 2000;342:1350-8.

20. Jin T, Almehed K, Carlsten H, Forsblad-d'Elia H. Decreased serum levels of TGF- $\beta 1$ are associated with renal damage in female patients with systemic lupus erythematosus. Lupus 2012;21:310-8.

21. Gagliardini E, Benigni A. Role of anti-TGF-beta antibodies in the treatment of renal injury. Cytokine Growth Factor Rev 2006;17:89-96.. 